\title{
THE EFFECT OF THE USE OF INTERACTIVE MULTIMEDIA ON THE IMPROVEMENT OF GEOGRAPHY LEARNING ACHIEVEMENT
}

\author{
M. Kurniawan Arif Syaefulloh ${ }^{1}$, Dyah Respati Suryo Sumunar ${ }^{2}$ \\ ${ }^{1,2}$ Departement of Geography Education \\ Yogyakarta State University, Indonesia \\ Email: kurniawan_shinyo@yahoo.com,respatisuryo@yahoo.com
}

DOI: $10.19184 /$ geosi.v2i1.7470

Article History: Received Date $20^{\text {th }}$ April 2018, Accepted Date $25^{\text {th }}$ April 2018, Published Date $30^{\text {th }}$ April 2018

\begin{abstract}
This research aimed to discover the effect of using interactive multimedia on the improvement of (2) geography learning achievement, and (2) learning interest of Grade students IPS of MA El Bayan Majenang. This study was a quasi-experiment using the quantitative approach. The population was 106 grade XI students IPS. A sample of 36 students was established the cluster sampling technique. The data collection used an achievement test, questionnaire on interest in learning, observation and documentation. The data analysis technique used was the inferential statistical technique. The hypothesis testing was performed using the MANOVA test with SPSS 20 program. The results of the study were follows. (1) the error rate (p) geography learning result was 0.009 . Because it was smaller than 0.05 , there was an effect of the use of interactive multimedia on the achievement of geography learning.(2) the level of error (p) interest in learning was 0.00. Because it was smaller than 0.05, there was an effect of the use of interactive multimedia on the improvement of students' learning interest (3) From MANOVA statistic test, it could concluded that there was an improvement in geography learning achievement and interest of the students before and after the treatment as the experimental class with the average increase of 35.55 and 11.55 respectively. While the improvement of geography learning achievement and interest in learning of the control class was averagely 29.02 and 2.86 respectively.
\end{abstract}

Keywords : Interactive multimedia, Geography Learning Achievement, interest in learning 


\section{INTRODUCTION}

Education is a very important thing for the survival of human life. Education is implemented in the form of learning and learning process, with the aim that the learner can develop the potential that is in him. If someone has a good education, it will automatically have a good knowledge of science. This shows the importance of education for human life and has various functions to support one's future. The world of education has been known for learning activities. Learning is a programmatic undertaken by teachers in instructional design that creates a process of interaction between fellow students, teachers with students and with learning resources. Learning in the system approach is a unity of learning components that mutually support each other, one of which is the learning media.

The use of creative learning media will increase the likelihood of students to learn more, remember what is learned better, and improve the skills of students in accordance with the purpose of learning. Currently the innovation of information and communication technology continues to be done for the purposes of learning activities, one of the breakthrough is the use of interactive multimedia in learning. Susilana (2008: 10) explains that the use of multimedia is expected students will be easier to determine with what and how students to be able to absorb information quickly and efficiently. The use of interactive multimedia in teaching and learning can generate new desires and interests, generate motivation and stimulation of learning activities, and even bring psychological influences on students. In addition to generating motivation and interests of students, interactive multimedia can also help students improve understanding, present data with interesting and reliable, facilitate interpretation of data, and condense information.

Characteristics of learning geography itself there are materials that are abstract, because it deals with physical and social phenomena so that the need for interactive multimedia to visualize the abstract thing in the class so that the intended concept can be understood well. This is supported by McKagan et al. (2007) that students will more easily understand the concept of abstract quantum mechanics with the help of interactive software. In addition students become more independent and active in the learning process either directly or indirectly.

In fact, not many teachers use the media. Media limitations or the ability of teachers to create learning media in schools, encourage teachers to use only lecture methods without any media that can support the material delivered because it is considered easier to do. This kind of learning makes some passive students and is indicated by the behavior of students who 
play mobile, sleep and chat with friends. The result of observation at MA El Bayan Majenang shows that learning is still centered on teachers and teachers still using lecture method and concept map in geography learning activities. Preliminary study results revealed learning outcomes of students in MA El Bayan Majenang in Geography subjects is still relatively low. The average grade of UAS Geography subjects of class X students in the even semester of the academic year 2016/2017 only reached an average score of 70 under KKM 75. In addition, the initial interest questionnaire test results obtained data that the still low interest in learning IPS class XI students in MA El Bayan Majenang. Then came the idea to overcome the problem one of them using interactive multimedia in learning geography. The use of interactive multimedia is expected to be one way to increase students' understanding of the concepts and materials learned geography, as well as increasing interest in students. If the learning interests of students increase, then the learning outcomes of students can also increase.

\section{METHODS}

This study was conducted to obtain an overview of the effect of using interactive multimedia to improve the learning outcomes of geography and learning interests of students. The method used in this research is the experimental method. The pseudo-experimental method in this study is used so that the researcher can analyze the difference between the experimental class and the control class given different treatment. The research design used in this research is the pretest posttest control group design (Randomized Subjects, PretestPosttest Control Group Design). This research uses two classes, namely experimental class and control class, where the experimental class is the group given a certain treatment, while the control class is the group given different treatment (treatment) as the comparison in the research. The experimental research design is as follows.

Table 1.

Randomized Subjects, Pretest-Posttest Control Group Design

\begin{tabular}{|c|c|c|c|}
\hline Grup & $\begin{array}{l}\text { (Pretes } \\
\text { t) }\end{array}$ & $\begin{array}{c}\text { Treatme } \\
\text { nt }\end{array}$ & $\begin{array}{c}\text { (Post } \\
\text { test) }\end{array}$ \\
\hline $\begin{array}{c}\text { Experiment } \\
\text { Class }\end{array}$ & $\mathrm{T} 1$ & $\mathrm{X}_{1}$ & $\mathrm{~T} 2$ \\
\hline $\begin{array}{c}\text { Control } \\
\text { Class }\end{array}$ & $\mathrm{T} 1$ & $\mathrm{X}_{2}$ & $\mathrm{~T} 2$ \\
\hline
\end{tabular}

Source : Sukardi (2015: 185) 
Information :

$\mathrm{T}_{1}$ : Pretest is intended to determine the interest and students' initial learning outcomes

$\mathrm{T}_{2}$ : Posttestis intended to determine the interest and learning outcomes of students after being treated

$\mathrm{X}_{1}$ : Geography Learning using Interactive Multimedia

$\mathrm{X}_{2}$ : Geography learning using media Textbooks

The research procedure performed is shown in the following figure.

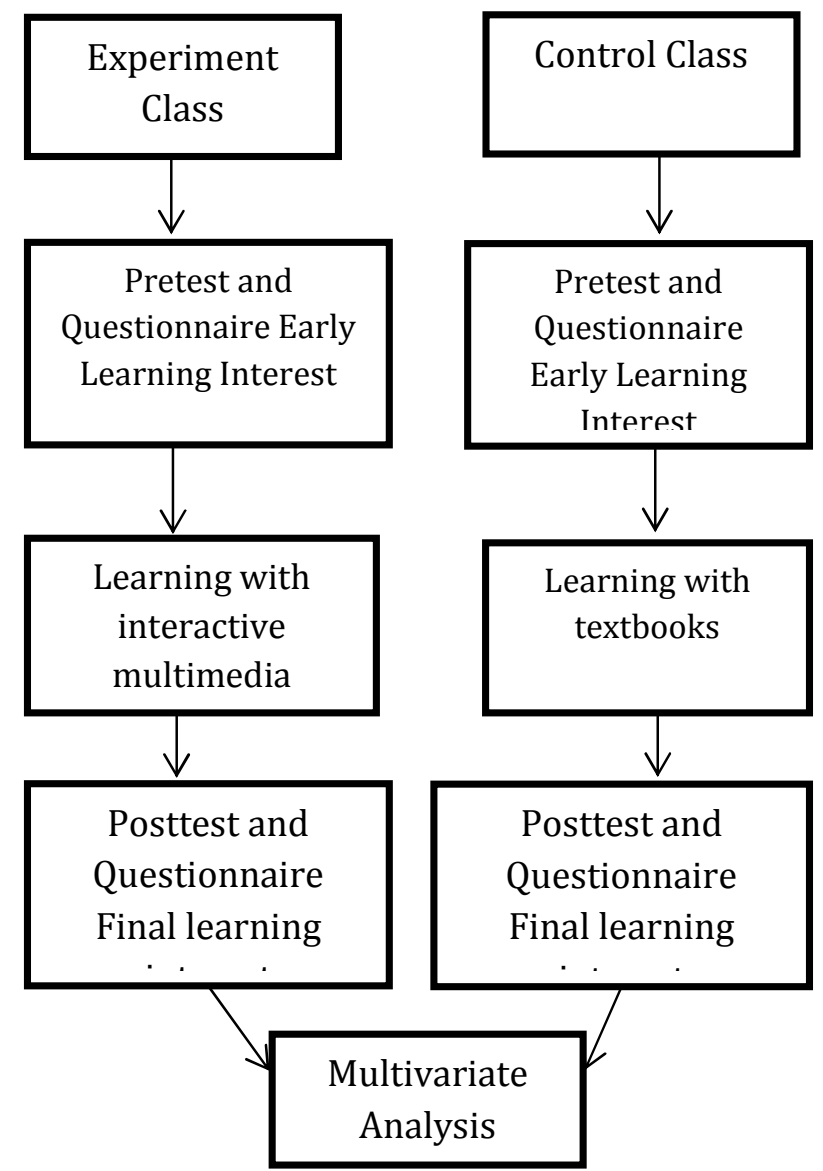

Figure 1. Research Procedure

This research procedure showed two different treatments, which will be given a pretest and initial interest questionnaire then after that a new learning which is done between experimental class that is class XI IPS 3 MA El Bayan Majenang with control class that is XI IPS MA Pesantren Pembangunan (PP) Majenang different treatment. After giving treatment (treatment) is given a final test (posttest) and a questionnaire of final interest to know the learning outcomes and interests students student. 
The research was conducted in El Bayan Majenang MA and MA PP Majenang started at the beginning of the first semester, ie in July 2017 until September 2017 on the learner class XI IPS Academic Year 2017/2018.

Population to be studied in this research is all students of class XI IPS at MA El Bayan Majenang academic year 2017/2018 amounted to 106 students who are divided into three classes and students class XI IPS in MA Majenang MA amounting to 36 students in one class. Research sampling with cluster sampling technique is a sampling technique based on groups (classes) that provide equal opportunities for each element (member) of the population. Then selected randomly by drawing a class treated with learning using interactive multimedia in MA El Bayan Majenang which is used as experiment class and one class XI IPS from MA Majenang MA as control class treated with textbook.

Data collection techniques used in this study include achievement test, questionnaire (questionnaire) interest in students learn, observation, and documentation. The data collection instruments used in this study include: (1) test instruments consisting of pretest and posttest, and (2) non-test instruments consisting of an initial interest interest questionnaire and a questionnaire of students' ultimate learning interest.

Data analysis technique in this research is inferential statistical technique. According to Hinkle in Sukardi (2011: 67) says that "inferential statistics are procedures used by researchers to draw conclusions from statistical samples to relate to population parameters". So the analysis of this data can be used to determine the extent to which the similarity between the results obtained from a sample with the results to be obtained from the population as a whole. The research data analyzed were initial and final conditions data on aspects of learning outcomes and the interests of students. This study aims to determine whether there is influence of the use of interactive multimedia to improve learning outcomes geography and interest in students learning classes XI IPS MA El Bayan Majenang. To test the research hypothesis, the collected research data was analyzed by MANOVA (multivariate Analysis of Variance) test using SPSS 20.0 program.

\section{RESULTS AND DISCUSSION}

1. Results

The results of this study were obtained from pretest and experimental class data and experimental class which aimed to know the influence of the use of interactive multimedia in the form of flash and powerpoint on the learning result of the students' geography on the 
biosphere material, which in the experimental class using interactive multimedia flash and powerpint and control classes using textbooks and lectures. Based on the result of the calculation of research data about the test of experimental geography of the experimental class, from 36 students sampled, the average pretest value of 44,30 and posttest 79,86, standard deviation pretest 10,89 and posttest 9,52 . The result of the test result of control class geography study, from 36 students who were sampled, got pretest value of 40,41 and posttest 69,44 , standard deviation of pretest 12,26 and posttest 9.83 . A summary of the gain data of students' abilities is presented in the following table.

Table 2.Data Enhancement Gainscore Learning Outcomes

\begin{tabular}{|c|c|c|c|}
\hline \multirow{2}{*}{ Class } & \multicolumn{2}{|c|}{ Average } & \multirow{2}{*}{ Gain } \\
\cline { 2 - 3 } & Pretest & Posttest & Ga, \\
\hline $\begin{array}{c}\text { Experiment } \\
\text { Class }\end{array}$ & 44,30 & 79,86 & 35,56 \\
\hline $\begin{array}{c}\text { Control } \\
\text { Class }\end{array}$ & 40,41 & 69,44 & 29,03 \\
\hline
\end{tabular}

The table shows the highest increase of students' learning result is in the experimental class that is the class given treatment using interactive multimedia that is equal to 35,56 . While in the control class, the class treated using textbooks increased by 29.03 . The average increase in the ability of students treated by using interactive multimedia is higher than the increase in the average of classes treated using textbooks.

\section{Discussion}

Data Interest in early learning of students derived from the data score questionnaire interest in learning geography given before the learning is done. The result of the questionnaire of early learning interest in the highest grade experimental grade was at 75, while the lowest score was 41 . Then the result of the initial interest interest questionnaire in the highest value control class was at 76 , while the lowest score was 42 . the result of questionnaire of the final learning interest in the experimental class showed the highest score was 77 , while the lowest score was 53 . Then the final learning interest questionnaire in the control class showed the highest value was 75 , while the lowest score was 44 . the result of early interest and interest data shows that it can be seen there is increasing interest in students students in the classroom experiments using interactive multimedia that is equal to 11.55 . Meanwhile, the increase of students' learning interest in the control class using textbook is 
only 2.86. This suggests that the average increase in students 'learning interest in the experimental class is higher than the average increase in students' learning interest in the control class.

MANOVA test on Multivariate Tests with error level less than 0.05 that is 0.00 , meaning $\mathrm{HO}$ is rejected. So it is proven that there is influence of the use of interactive multimedia to improve learning outcomes geography and interest in learning geography students XI IPS MA EL Bayan Majenang. Furthermore, based on table 15. Test of BetweenSubject Effects, shows that the relationship between interactive multimedia (X) with geography learning result has an error rate smaller than 0.05 that is equal to 0.09 . This indicates that there is an influence of the increase of Geography learning result caused by difference of usage of instructional media (X). While the relationship between interactive multimedia $(\mathrm{X})$ with the learning interests of students have an error rate smaller than 0.05 that is equal to 0.00 . This shows that there is an increasing interest of students are caused by differences in the use of instructional media (X).

The results of the MANOVA test with Multivariate Tests and Test of Between-Subjects Effects final learning outcomes data and questionnaire data interests of students showed the influence of the use of interactive multimedia to improve learning outcomes geography class XI IPS MA El Bayan Majenang.

\section{CONCLUSIONS}

Some things that can be concluded from the implementation of this research are as follows. (1) Classroom learning using interactive multimedia shaped flash and powerpoint makes it easier for students to understand biosphere material compared to conventional learning using textbooks and lectures. It is reviewed from the results of the study there is an increase in learning outcomes geography students class XI IPS 3 MA El Bayan Majenang. Average grade increase (Gainscore) class XI IPS 3 MA El Bayan Great as experimental class of 35.55. While the average grade increase (Gainscore) class XI IPS MA PP Majenang as a control class of 29.02. (2) There was an increase in students 'learning interest in the experiment class significantly with Gainscore 11.55, while the students' learning interest in the control class only increased with Gainscore 2.86 .

Based on these conclusions then can be submitted some suggestions as follows. Learning in the classroom by using interactive multimedia is expected to be used as an alternative for teachers in an effort to improve learning outcomes and learning interests of 
students in teaching and learning activities geography. Learning using interactive multimedia requires more preparation time and meetings to make the research more optimal.

\section{REFERENCES}

Anderson, L. W. dan David R Kratwohl. (2010). Kerangka Landasan Untuk Pembelajaran, Pengajaran, dan Assesment (Penerjemah: Prihantoro, A. dari A Taxonomy for Learning, Teaching, dan Assesing: A Revision of Blomm's Taxonomy of Educational Objectives A Bridged Eddition: Addison Wsley Longman, Inc. 2001). Yogyakarta: Pustaka Pelajar.

Arsyad, A. (2010). Media Pembelajaran. Jakarta : Raja Grafindo Persada.

Mardapi, D. (2008). TeknikPenyusunanInstrumen Tes dan Non Tes. Yogyakarta :MitraCendekia Press.

McKagan, S. B., Perkins, K. K., Dubson, M., Malley, C., Reid, S., LeMaster, R., and Wieman, C. E. (2007). Developing and Researching PhET simulations for Teaching Quantum Mechanics. In American Journal of Physics 76, 406

Pasya, G. K. (2006). Geografipemahamankonsep dan metodologi. Bandung: Buana Nusantara.

Sudjana, N. (2010). Media Pengajaran. Bandung: Algesindo Sinar Baru.

Sukardi. (2015). Metodologi Penelitian Pendidikan. Jakarta : Bumi Aksara.

Susilana, R. \& Riyana, C. (2008). Media Pembelajaran. Bandung : Universitas Pendidikan Indonesia. 